\title{
Pendidikan Agama Kristen dalam Perspektif Teori Perkembangan Iman James W. Fowler
}

\author{
Christian Religious Education
}

in the Perspective of the Theory of Faith Development by James W. Fowler

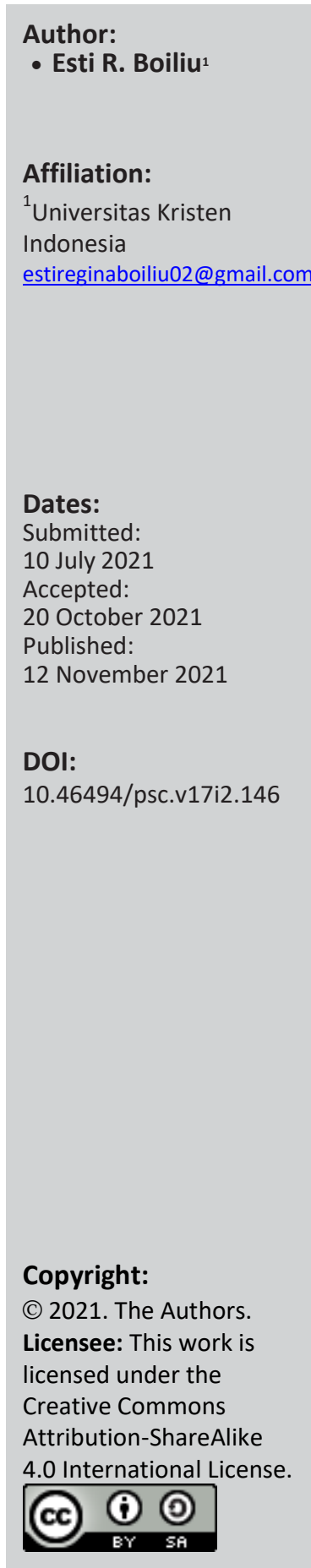

\begin{abstract}
James W. Fowler's theory of faith development plays a role in seeing the growth of human faith in God. In this case, Fowler formulated several stages in developing one's faith, including the steps of the faith development of several people who have different beliefs. This study raises the thoughts of James Fowler and its relevance to Christian Religious Education today so that this research results in an understanding that in the context of Christian Religious Education, the development of faith needs to be instilled in students from an early age by educators. The method used in this paper is the literature study method.

[Teori perkembangan iman James W. Fowler berperan dalam melihat perkembangan iman manusia kepada Tuhan. Dalam hal ini, Fowler merumuskan sejumlah tahapan dalam proses perkembangan iman seseorang mencakup tahap-tahap perkembangan iman dari beberapa orang yang memiliki kepercayaan berbeda-beda. Penelitian ini mengangkat pemikiran James Fowler dan relevansinya terhadap Pendidikan Agama Kristen masa kini sehingga penelitian ini menghasilkan pemahaman bahwa dalam konteks Pendidikan Agama Kristen, perkembangan iman perlu untuk ditanamkan kepada naradidik sejak kecil oleh para pendidik. Metode yang digunakan dalam tulisan ini adalah metode studi pustaka.]

Research Contribution: Hasil riset berkontribusi pada pemanfaatan konstruksi teori James W. Fowler sebagai persepektif analisis di dalam disiplin ilmu pendidikan agama Kristen.
\end{abstract}

Keywords: christian education, faith, religious education, development, social

\section{Pendahuluan}

$\mathrm{E}$ ra globalisasi merupakan sebuah kenyataan yang harus dihadapi oleh setiap orang. Pengaruh globalisasi berdampak kepada banyak bidang, baik dalam bidang pendidikan, kebudayaan, ekonomi, politik, sosial, dan lain sebagainya. Globalisasi merupakan sebuah fenomena yang bukan baru melainkan sebuah proses yang sudah terjadi sejak abad-abad sebelumnya. Dalam artikelnya, Setyaningsih menguraikan ciri-ciri perkembangan globalisasi yang terjadi yaitu berkaitan dengan alat-alat seperti telepon, televisi dan internet, dan aplikasi terbaru lainnya yang. Selain itu, terjadinya meningkatnya pada bidang kebudayaan, di mana adanya pengenalan budaya lokal secara internasional melalui alat dan media yang ada sehingga membuat 
masyarakat juga ikut merasakannya. Sementara Di bidang pendidikan, persaingan studi tidak lagi secara nasional tetapi juga Melalui perkembangan tersebut, berdampak kepada hal lain, misalnya peningkatan masalah bersama yang ditemukan pada bidang lingkungan hidup, krisis multinasional, inflasi keagamaan dan lainlain. ${ }^{1}$ Selain itu, dalam bidang pendidikan pun mengalami perkembangan pesat, di mana semua pelajar dan pendidik dalam mengakses informasi-informasi mengenai pendidikan dengan sangat mudah. Akan tetapi tentunya ada hal-hal yang menjadi perhatian khusus selain intelektual, yaitu spiritual atau iman. Dalam konteks pembasahan ini adalah iman secara Kristiani.

Secara sederhana, iman adalah sebuah kepercayaan/keyakinan terhadap suatu hal. Hermanto Suanglangi mengutip pendapat beberapa tokoh yang menjelaskan, bahwa Kata iman dalam bahasa lbrani, berasal dari kata "Emun", yang berarti kesetiaan, dan kata "Batakh", yang berarti percaya, sedangkan dalam bahasa Yunani, iman berasal dari kata "Pistis", (kata benda), yang berarti kepercayaan, keyakinan, dan iman itu sendiri, dan lman Kristen dan akal budi kata "Pisteuo" (kata kerja), yang berarti, percaya, meyakini, mengimani. Sementara Dalam istilah bahasa Inggris kata ini mempunyai pengertian yang sama dengan pengertian di atas, yaitu "Faith" yang artina kepercayaan, dan keyakinan. ${ }^{2}$ Dengan demikian, iman merupakan pengakuan atau kepercaaan kepada sesuatu hal, dalam konteks ini adalah iman atau kepercayaan kepada Yesus Kristus. Iman/kepercayaan yang dimiliki oleh seseorang tidak langsung penuh, melainkan membutuhkan proses untuk berkembang, dan

\footnotetext{
${ }^{1}$ Setyaningsih, "Dampak Globalisasi Terhadap Generasi Muda,” STHD Jateng 148 (2019): 148-62.

${ }^{2}$ Hermanto Suanglangi, "Iman Kristen Dan Akal

Budi," Jurnal Jaffray 2, no. 2 (2005),

https://doi.org/10.25278/jj71.v2i2.16o.

${ }^{3}$ Sonny Eli Zaluchu, "Model Pendidikan NasionalisReligius Yahudi, Dan Refleksinya Dalam Pendidikan Teologi Di Indonesia," KURIOS (Jurnal Teologi Dan
}

secara internasional, kemudian akses proses belajar mengajar dapat dilakukan denga cara yang lebih mudah.

untuk membantu perkembangan iman tersebut maka harus ada sebuah wadah yaitu

Pendidikan Kristen adalah sebuah ranah di mana adanya proses belajar mengajar tentang Allah Tritungga dan karya-karya-Nya, atau dengan kata lain Pendidikan Kristen dilakukan untuk memperkuat hubungan antara orang percaya dengan Kristus, diperlukan pendidikan untuk mengenal siapa dan bagaimana Kristus berkarya dalam sejarah kehidupan manusia. Maksudnya diperlukan adanya pendidikan yang berorientasi kepada Kristus, itulah yang disebut Pendidikan Agama Kristen (PAK). 3

Menurut Robert W. Pazmino dalam bukunya yang berjudul Fondasi Pendidikan Kristen, bahwa untuk menjalankan pendidikan Kristen yang benar maka, para pendidik Kristen, harus dengan teliti menganalisis apa yang menjadi fondasi dari Pendidikan Kristen itu. Alkitab merupakan sumber utama agar untuk dapat mengajarkan kekristenan di dalam dunia Pendidikan Kristen. 4 Dengan kata lain Alkitab menjadi sumber kebenaran dan literasi utama dalam pendidikan Kristen. Oleh karena itu, pendidikan Kristen dapat dikatakan sebagai upaya Allah melalui manusia dengan berulang-ulang dalam rangka memberikan pengetahuan, beragam macam nilai Kristiani, sikap Kristiani, berbagai keterampilan serta tingkah laku yang berorientasi kepada iman Kristen. Hal ini dilakukan dalam rangka transformasi diri dari naradidik secara pribadi, maupun berkelompok dengan terstruktur dibawah tuntunan Roh Kudus. Dengan demikian

Pendidikan Agama Kristen) 7, no. 2 (2021): 232-42, https://doi.org/https://doi.org/10.30995/kur.v7i2.29 9.

4 Robert W. Pazmino, Fondasi Pendidikan Agama Kristen (Jakarta: BPK Gunung Mulia, 2018), 14. 
Pendidikan Kristen dapat diterapkan ditengah-tengah keluarga, gereja, sekolah, dan masyarakat sekalipun. Maksudnya Pendidikan Kristen itu bukan hanya teori belaka yang disalurkan melainkan lebih kepada praktik dari apa yang telah difirmakan oleh Allah melalui Alkitab. Hal ini dijelaskan oleh E. G. Homrighausen dan I. H. Enklaar, bahwa adalah pendidikan yang diberikan kepada setiap orang tanpa memandang usianya dalam membangun persekutuan antara manusia dengan sesamanya dan manusia dengan Tuhan.5 Sementara, John Piper John mempertegas posisi PAK ialah bukan hanya soal belajar Alkitab, melainkan posisi PAK adalah merefleksikan apa yang ada dalam Alkitab dengan akurat demi kebaikan setiap orang. 6 Dengan demikian dapat disimpulkan bahwa PAK sebenarnya ialah suatau usaha sadar yang dikerjakan oleh gereja (orang percaya, sebab orang percaya merupakan gereja yang hidup) untuk membawa setiap orang mengenal karya-karya penyelamatan Allah di dalam Anak-nya yitu Yesus Kristus. Artinya bahwa orang percaya menjadi surat Kristus yang dapat du baca oleh orang lain melalui sikap dan perbuatannya sebagai bentuk pertumbuhan imannya.

Perubahan zaman membuat banyak orang kurang dalam merespons agamanya, melainkan lebih mementingkan kehidupan diri sendiri dengan mengikuti perkembangan zaman yang berdampak negatif. Selain itu, proses pembelajaran diutaman kepada intelektual dan mengabaikan spiritual. Pada konteks PAK, Daniel Nuhamara menjelaskan bahwa, perkembangan iman merupakan komponen penting dari kehidupan seseorang, baik secara fisik, psikis, sosial, dan lain-lain. ${ }^{7}$ Dalam tulisannya, Noh Ibrahin Boiliu

5 E.G. Homrighausen dan I. H. Enklaar, Pendidikan Agama Kristen (Jakarta: BPK Gunung Mulia, 2008), 25-26.

${ }^{6}$ John Piper, The Pleasures Of God: Meditations ON God's Delight in Being God (Newyork: Multomah Publisher, 2012), 23.

7 Daniel Nuhamara, Pendidikan Agama Kristen

Remaja (Bandung: Jurnal Info Media, 2008). mengatakan bahwa, PAK tidak hanya berbicara tentang bagaimana tindakan anakanak dalam menghafal jumlah kata dalam Alkitab, Kesepuluh Firman, Tujuh perkataan Yesus di atas kayu salib, ataupun hal lainnya. Melainkan ada keterlibatan tindakan mendidik sehingga mencapai kedewasaan di dalam Kristus. ${ }^{8}$ Melihat bahwa Pendidikan Agama Kristen (PAK) bertujuan untuk bagaimana mendidik para naradidik atau jemaat untuk mengerti, memahami, serta mengaktualisasikan ajaran kekristenan berdasarkan Firman Allah, maka tentu tidak terlepas dari bagaimana para pendidik mengetahui sampai di mana tahap perkembangan iman para naradidik agar bisa dijadikan sebagai acuan mengajar PAK dalam hal juga membimbing naradidik untuk melewati setiap proses sampai pada kematangan iman. 9 Untuk itu sangat perlu bagi para pendidik khususnya para pendidik PAK untuk belajar tahapan perkembangan iman yang dikemukakan oleh James Fowler dan bagaimana relevansinya terhadap PAK masa kini.

Terdapat beberapa penelitian terdahulu yang membahas tentang judul yang dibahas dalam artikel ini, antara lain: pertama, Yunardi Kristian Zega (2020) yang membahas tentang bagaimana teori yang dibangun oleh Fowler yaitu perkembangan iman dapat diimplikasikan dalam konteks Pendidikan Agama Kristen. Penelitian tersebut menghasilkan pemahaman bahwa Pendidikan Agama Kristen berperan sebagai fasilitator untuk perkembangan iman remaja menuju tahap yang lebih tinggi. Hal tersebut dapat dilakukan dalam keluarga, sekolah maupun di gereja. Kedua, Feriyanto (2019) mengkaji tentang bagaimana teori perkembangan iman

\footnotetext{
${ }^{8}$ Noh Ibrahim Boiliu, "Misi Pendidikan Agama Kristen Dan Problem Moralitas Anak," Regula Fidei 1, no. 1 (2016): 115-40, http://repository.uki.ac.id/406/. 9 Ronny Simatupang \& Tianggur Medi Napitupulu, Hasudungan Simatupang, Pengantar Pendidikan Agama Kristen (Yogyakarta: PBMR ANDI, 2020), 211.
} 
menurut Fowler melalui cerita Alkitab yang diimplikasikan dalam Sekolah Minggu Gereja Toraja di jemaat Karassik. Hasil penelitiannya adalah diupayakan agar dalam menyampaikan Firman Tuhan kepada anak sekolah Minggu memasukkan aplikasiaplikasi konkrit untuk dapat menumbuhkan iman anak-anak. Ketiga, Denny Surya Saputra (2017), melakukan penelitian tentang Perkembangan Spiritual Remaja SMA Dharma Putra berdasarkan teori perkembangan iman menurut James W. Fowler, hasilnya menunjukkan bahwa tingkat spiritual pada SMA Dharma Putra didominasi oleh tiga tahap. Keempat, Jeneman Usmany (2018), tentang bagaimana spiritualitas (kerohanian) guru PAK dalam teori perkembangan kepercayaan Fowler dan teori perkembangan moral Kohlberg: penafsiran perspektif Alkitab. Hasil penelitian ini memberikan pemahaman bahwa spiritualitas pendidik/guru dapat mempengaruhi perkembangan spiritualitas anak-anak. Berdasarkan beberapa penelitian di atas belum ada pembahasan yang spesifik tentang penelitian ini.

\section{Metode}

Jenis Penelitian ini yang digunakan dalam penelitian ini adalah metode kualitatif, di mana materi yang dikumpulkan oleh penulis tidak berupa angka, melainkan dari buku, jurnal, internet dan sumber informasi lainnya. ${ }^{10}$ Data yang diperoleh dari hasil kajian pustaka/dokumenter disusun dan dijelaskan untuk mendapatkan studi deskriptif tentang pembahasan mengenai relevansi daripada teori perkembangan iman James W. Fowler terhadap Pendidikan Agama Krsten.

\section{Pembahasan}

\section{Biografi Singkat James Fowler}

James W. Fowler lahir di North Carolinam Amerika Serikat pada tahun 1940, dan beliau menutup usianya pada tanggal 16 Oktober 2015. ${ }^{11}$ Fowler mulai mengembangkan teorinya yaitu teori perkembagan iman, pada saat menjabat sebagai wakil pimpinan di sebuah perubahaan yaitu pusat pembinaan agama dan kebudayaan di tempat lahirnya (antara tahun 1968 - 1969). Ditempat tersebut dinamakan Interpreter's House, pekerjaannya adalah sebagai pakar bimbingan dan konseling. Fowler mendengarkan banyak kesulitan hidup orangorang dan menjadi saksi perjuangan mereka dalam tujuan untuk menemukan kembali makna hidup. Disinilah Fowler mendapatkan suatu gambaran yaitu struktur pikiran yang biasa ditemukan pada banyak orang melalui hasil wawancara dari 500 orang yang berasal dari anak-anak dan orang tua. Hasil analisis wawancara tersebut memungkinkan Fowler untuk menyusun sebuah teori yang dikenal "Faith Development Theory (teori perkembangan iman)". Teori ini menjadi teori baru yang yang digunakan untuk melihat tahapan perkembangan iman, baik secara empiris maupun teoritik.

Seiring dengan berjalannya waktu, maka Fowler memutuskan untuk pindah ke Harvard (1969) dengan tujuan untuk mendalami secara mendalam tentang struktur-struktur pikiran yang ditemukan pada tempat diman ia bekerja, yaitu tentang perkembangan iman secara berangsur-angsur mulai menuju kepercayaan yang matang diinspirasi oleh teori Jean Piaget, Erik Erikson

\footnotetext{
${ }^{10}$ Sonny Eli Zaluchu, "Metode Penelitian Di Dalam Manuskrip Jurnal Ilmiah Keagamaan [Research Methods in Religious Scientific Journal Manuscripts]," Jurnal Teologi Berita Hidup 3, no. 2 (March 25, 2021): 249-66, https://doi.org/10.38189/jtbh.v3i2.93.
}

${ }^{11}$ Yunardi Kristian Zega, "Teori Perkembangan Iman Remaja Menurut James Fowler Dan Implikasinya Bagi Pendidikan Agama Kristen," Jurnal Pendidikan Dan Kebudayaan Missio 12, no. 2 (2020): 140-51, https://doi.org/https://doi.org/10.36928/jpkm.v12i2. 488 . 
dan Lawrence Kohlberg. ${ }^{12}$ Fowler berusaha untuk menggabungkan dan mengembangkan dua tipe psikologi, psikososial dan struktur genetik menjadi teori perkembangan iman.

Dalam penelitiannya, Fowler juga menjelaskan bahwa teori struktur perkembangan iman merupakan penelitian deskriptif sekaligus normatif. Hasil dari teori ini dijelaskan oleh Hasan bahwa dapat menunjukkan serta membuktikan perkembangan iman secara sistematis sesuai dengan perkembangan umur dari anak-anak hingga dewasa, di mana dalam proses perkembangan tersebut, seseroang dapat memahami bagaimana dan mengapa ia percaya bukan hanya kepercayaan yang asbtrak. Dari kejadian ini, maka Fowler mengambil kesimpulan dengan menggapnya bahwa kepercayaan atau agama apapu yang dianut semestinya menjadi dasar untuk menolong seseorang mengalami peningkatan iman menuju arah yang lebih tinggi. Melalui penelitiannya, Fowler melakukan tahapan dan menemukan cara yang bertujuan untuk mendukung seseorang agar tidak menetap pada tingkatan iman yang rendah, melainkan semakin meningkat menuju iman yang lebih tinggi atau mengalami kedewasaan dalam iman. ${ }^{13}$ Dengan demikian dapat disimpulkan bahwa proses pertumbuhan iman seseorang dapat terjadi melalui beberapa tingkatan sesuai dengan pertumbuhan usia dan proses ini secara kontinu berlangsung selama masa hidup manusia tersebut.

\section{Cara pandang James Fowler terhadap Perkembangan Iman}

Fowler berpandangan bahwa meyakini, mempercayai dan mengimani, semuanya

\footnotetext{
12 Denny Surya Saputra, "Perkembangan Spiritual Remaja SMA Dharma Putra,” Jurnal Psikologi 15, no. 9 (2018): 64 of 67; Johan Hasan, "Sumbangsih Pemikiran James W. Fowler Dalam Pendidikan Agama Di Perguruan Tinggi Indonesia," Respons: Unika Atma Jaya 23, no. 02 (2018): 185-204. 13 Zega.
}

berasal dari satu suku kata yaitu kata kerja "faithing", yang diartikan sebagai suatu komitmen iman seseorang pada pusat transenden dari nilai dan kuasa (power), yang dengan-Nya, sang pribadi memaknai seluruh peristiwa dalam kehidupannya. Dalam hal ini, Johan Hasan berpendapat bahwa iman bisa saja tidak pada tradisi agama-agama yang kita kenal selama ini di Indonesia. Selain itu, berbicara tentang iman juga bukan sekadar percaya atau dengan mengatakannya dengan suara yang lantang agar didengar oleh orang lain. Pernyataan tentang iman dan formulasi doktrin tertentu bukan dari suatu agama pula, karena seorang yang tidak beragama pun menaruh iman, harapan, visi bahkan totalitas hidupnya pada sesuatu yang lain yang dianggap penting sebagai dasar yang menggerakannya dalam hidup. ${ }^{14}$ Kenyataan ini terjadi dalam setiap orang disekitar kita. Setiap orang mengalami pengalaman iman yang berbeda dengan waktu dan tahapan yang berbeda juga.

Fowler memberikan gambaran tentang Faith Development Theory (Teori Perkembangan Iman) dalam 3 bagian, yakni: 15

Pertama, kepercayaan (faith). Fowler memandang kepercayaan sebagai bentuk upaya seseorang dalam merubah, menciptakan kemudiaan memelihara hal tersebut sebagai hal yang sangat berarti bagi kehidupannya. Terdapat 3 aspek yang dijelaskan oleh Fowler, yaitu: (1) iman adalah cara orang melihat hubungannya dengan orang lain, (2) iman sebagai representatif paradigma seseorang dalam mengartikan sesuatu secara umum dan mampu untuk mengartikan hal tersebut secara khusus pula, (3) iman dipahami sebagai pandangan seseorang tentang keseluruhan daripada nilai-

14 Johan Hasan, "Sumbangsih Pemikiran James W. Fowler Dalam Pendidikan Agama Di Perguruan Tinggi Indonesia." 188

15 Yunardi Kristian Zega, "Teori Perkembangan Iman Remaja Menurut James W. Fowler Dan Implikasinya Bagi Pendidikan Agama Kristen.", 142. 
nilai kehidupan, serta kekuatan merupakan kewajiban yang harus dimiliki oleh seseorang karena hal tersebut berguna bagi diri sendiri dan sesama manusianya.

Kedua, perkembangan (development). Perkembangan tersebut dikenal sebagai proses perubahan kematangan wujud iman seseorang seseorang yang terjadi melalui beberapa tahap. Fowler menjelaskan bahwa perkembangan (development) berkaitan mental seseorang diproses dalam segala bidang dan pengalaman yang terjadi dalam kehidupannya. Kemudian hal tersebut dijadikan sebagai perumpamaan yang dapat ditafsirkan, diartikan dan dipahami dari masing-masing pribadi yang mengalaminya. Perkembangan dapat terbentuk dari masalahmasalah yang terjadi, karena dari masalah tersebut maka pribadi yang menjadi kuat dalam menghadapi setiap kenyataan yang terjadi.

Ketiga, teori (theory). Menurut Fowler, teori dapat tercipta dari setiap ilmu pengetahuan yang didalamnya terdapat sekumpulan hipotesis. Perlu dicatat bahwa teori bukan berbicara tentang pengetahuan belaka, melainkan pengetahuan yang kemudian diaplikasikan melalui praktiknya. Secara psikologis, teori perkembangan memiliki tujuan dalam untuk memahami serta merumuskan semua kejadian yang terjadi dalam perkembangan seseorang termasuk imannya. ${ }^{16}$ Jadi, Faith Development Theory (teori perkembangan iman) merupakan suatu usaha ilmiah yang dilakukan Fowler untuk menguraikan secara empiris dan teoritis seluruh proses perkembangan iman dalam pengalaman hidup setiap orang. Melihat analisis yang dilakukan, maka Fowler berhasil membedakan tahapan tahapan

\footnotetext{
16 Zega.

${ }^{17}$ Feriyanto, "Implementasi Cerita Alkitab Terhadap Perkembangan Iman Anak Sekolah Minggu Gereja Toraja Menurut Teori James W. Fowler Di Jemaat Karassik," Cura Animarum 1, no. 1 (2019): 7-18.
}

perkembangan iman seseorang dari usia anak-anak sampai orang dewasa.

Setelah menyelesaikan studinya, maka James Fowler menjadi pencetus teori perkembangan iman, yang kemudian teori tersebut diajukan untuk berfokus memotivasi seseorang dalam menentukan makna hidup, termasuk kepercayaannya, baik di dalam maupun di luar konteks agama. Berikut terdapat 6 tahapan perkembangan iman yang diajukan oleh Fowler ${ }^{17}$, yakni:

Tahap pertama, tahap iman intuitifproyektif atau intuitive-proyektive faith ${ }^{18}$ (umur 2-6 tahun). Tahap pertama ini merupakan tahap yang penuh dengan imajinasi, gambaran atau pengahayalan yang sangat mengesankan. Tahap ini membuat anak untuk aktif berekspresi tanpa merasa dikekang, kemudian proses berpikirnya pun masih sebatas hal-hal yang sederhana ada di depan mata. Ketidakpastian anak dalam berpikir pun merupakan bagian penting yang ada dalam tahap ini. Selain itu, orang dewasa menjadi sumber autoritas dan instansi kekuasaan akhir yang esktrem. Hingga pada perkiraan memasuki usia yang ke 2 Tahun, anak sudah memiliki kesanggupan dan berbahasa yang mana ia akan berusaha berusaha untuk menguasai dan menggunakan bahasa menurut gayanya sendiri sehingga terkadang terdengar tidak jelas dalam mengucapkannya. Selanjutnya dengan suatu cara yang baru, anak memiliki suatu tahap baru yaitu memiliki kemampuan sederhana untuk menyusun, mengatur, dan mengantarai seluruh relasinya, baik dengan diri sendiri, maupun bersama orang lain. Sementara perkembangan lainnya adalah semakin meluasnya daya gerak, fisik serta mental dari anak tersebut. ${ }^{19}$ Dalam Pendidikan Agama

\footnotetext{
${ }^{18}$ Agoes Dariyo, Psikolgi Perkembangan Dewasa Muda (Jakarta: Grasindo, 2008), 90.

${ }_{19}$ Feriyanto, "Implementasi Cerita Alkitab Terhadap Perkembangan Iman Anak Sekolah Minggu Gereja Toraja Menurut Teori James W. Fowler Di Jemaat Karassik, 12.”
} 
Kristen, pada tahap ini anak masih memiliki banyak waktu bersama keluarga/orang tua dirumah. Hal ini ditegaskan oleh Talizaro Tafona'o bahwa PAK dalam keluarga sangat penting, di mana dapat membantu orang tua mengerti bagaimana cara memperlakukan dan mendampingi anaknya ${ }^{20}$, termasuk membimbing pertumbuhan imannya untuk bertumbuh sesuai dengan kebenaran Firman Tuhan. Selanjutnya Ruwi Hastuti juga menjelaskan bahwa keluarga sebagai tempat yang disiapkan untuk untuk menabur serta menanamkan nilai-nilai kehidupan (Ul. 6:67). ${ }^{21}$ Sementara dalam artikelnya, Minggu menjelaskan bahwa apa yang dilakukan oleh orang tua menjadi pola selanjutnya yang akan dilakukan oleh anak ${ }^{22}$, sehingga orang tua perlu untuk menjaga setiap perilaku, perkataan dan sikap di dalam rumah. Dengan demikian, pada tahap ini, yang memiliki peran penting adalah orang tua/keluarga dalam membantu menumbuhkambangkan iman anak.

Tahap kedua, Iman Mitos-Harfiah (umur 6-12 tahun). Pada tahap ini, anak sudah berbicara dengan jelas, dan sudah bersosialisasi dengan lingkungan sekitar, baik dalam keluarga, sekolah maupun teman bermain. Iman percaya anak-anak masih dalam taraf yang sederhana, akan tetapi sudah bernalar untuk menyerap hal-hal yang logis, nyata namun tidak abstrak. Tahap ini juga, anak dengan mudah akan mempercayai apa yang diajarkan kepada mereka. ${ }^{23}$ Anak pada usia ini, memandang Tuhan berperan sebagai gambaran orangtua mereka. ${ }^{24}$ Pada tahap ini, anak berada dalam beberapa lingkungan yang

\footnotetext{
20 Talizaro Tafonao, "Peran Pendidikan Agama Kristen Dalam Keluarga Terhadap Perilaku Anak," Edudikara: Jurnal Pendidikan Dan Pembelajaran 3, no. 2 (2018). ${ }^{21}$ Ruwi Hastuti, "Pendidikan Agama Kristen Dalam Keluarga Sebagai Pusat Bermisi," Konfrensi Keluarga Kristen - The Great Commission 25, no. Juni (2018): 75-92.

${ }^{22}$ Minggus, "Pembelajaran Kontekstual Di Masa Pandemi Untuk Mengembangkan Spiritualitas Anak," PASCA: Jurnal Teologi Dan Pendidikan Agama Kristen, 2021, https://doi.org/10.46494/psc.v17i1.126.
}

berbeda, yakni lingkungan keluarga, sekolah, gereja dan lingkungan sekitar. Dengan demikin dalam proses PAK, diupayakan untuk bagaimana dapat mengkolaborasinya sehingga anak tetap memiliki perkembangan iman yang terus naik. Menurut Djoys Anneke Rantung, dalam situasi ini PAK harusnya berfungsi membuat orang-orang secara kreatif, mandiri, dan partisipatif menuju kebenaran Firman Tuhan. ${ }^{25}$

Tahap Ketiga, Iman Sintetik-Konvensional (umur 12-? tahun). Tahap ini dimulai dengan munculnya berbagai macam kemampuan dalam pengetahuan yang memaksa anak untuk kembali melihat apa yang harus dilakukan dalam dirinya, apa yang harus ia refleksikan dalam dirinya. Tahap ini juga, anak tidak lagi memandang Tuhan sebagai sesuatu yang jauh dan tidak bisa dijangkau, melainkan merekan akan mulai membangun hibungan pribadi bersama Tuhan. Keanehan yang terjadi pada tahap ini adalah, Tuhan digambarkan sebagai Tuhan yang sebagaimana diyakini oleh semua masyarakat pada umumnya. Artinya seolah-olah waha Tuhan nampak jelas dan sikap, nilai dan perilaku yang konvensional. Akan tetapi, hal positif yang ditemukan dalam tahap ini adalah mulai ada benih kepercayaan kepada pribadi yang lain, di mana anak sudah bisa berjanji untuk mempercayakan kehidupannya kepada pribadi yang menjadi idolanya. Sementara, negatifnya adalah anak-anak memiliki peluang untuk mempercayakan kehidupannya bahkan memiliki ketergantungan yang tidak sehat kepada idolanya seperti artis, dan tokoh favorit 
lainnya. Tahap ini membutuhkan pengawasan penuh dari orang tua untuk tetap menjelaskan kepada anak jika masih memiliki ketergantungan yang tidak sehat kepada pribadi lain yang bukan Tuhan. ${ }^{26}$ Dalam tahap ini iman anak tidak hanya sebatas mengenal, tapi sudah mengetahui bahkan mempersiapkan diri untuk mengikut Yesus, sehingga PAK juga tentunya memiliki peran aktif untuk mengarahkan dan membimbing anak-anak untuk berpegang tegu pada keyakinannya yaitu kepada Yesus Kristus.

Tahap Keempat, yaitu Iman IndividuatifReflektif (umur 18-? tahun). Ketika memasuki tahap ini, maka seseorang tidak lagi memberikan tanggung jawab imannya kepada orang lain, melaikan ia harus bertanggungjawab untuk diri sendiri. Contohnya, pada konteks gereja, usia ini merupakan usia di mana seseorang sudah beranjak remaja hingga dewasa, sehingg diwajibkan untuk mengikuti kegiatankegiatan kerohanian, termasuk di dalamnya dibaptis atau sidi baru. Anak pada usia ini memiliki banyak perubahan, baik secara fisik maupun secara psikis, bahkan sudah mengerti tentang banyak hal, dan ia akan memiliki banyak pertanyaan mengenai imannya. Terdapat 3 hal penting yang semestinya diketahui dalam tahap ini, antara lain: mulai muncul kesadaran yang jelas mengenai identitas diri, kemudian ia sudah bisa membedakan perbedaan yang timbul dalam dirinya. Berdasarkan hal tersebut, maka seseorang akan mulai refleksi diri sendiri, mulai mempertanyakan nilai-nilai kehidupan, serta memiliki pandangan mengenai hidupnya sendiri. Bahkan tahap ini juga

\footnotetext{
${ }^{26}$ Feriyanto, "Implementasi Cerita Alkitab Terhadap Perkembangan Iman Anak Sekolah Minggu Gereja Toraja Menurut Teori James W. Fowler Di Jemaat Karassik.", 13.

27 Feriyanto. 13

${ }^{28}$ Ya'aman Gulo, Rita Evimalinda, and Ardianto Lahagu, "Peran PAK Dalam Membentuk Mental Positif Generasi Kristen Di Era Millenial," Real Didache: Jurnal Teologi Dan Pendidikan Agama Kristen 5, no. 1 (2020): 17 .
}

memiliki kecepatan dalam memahami sesuatu serta memiliki pemikiran yang kritis terhadap suatu hal yang bekaitan dengan falsafah kehidupan, termasuk iman percayanya. ${ }^{27}$ Peran PAK dalam tahap ini, adalah membantu dan membimbing serta memberikan pemahaman mendalam tentang beriman kepada Yesus Kristus serta sadar benar bahwa pengorbanan Yesus Kristus yang dilakukan untuk dirinya. ${ }^{28}$

Tahap Kelima, Iman Kongjungtif (umur 30-?). Dalam memasuki tahap iman kongjungtif, seseorang sudah mampu membedakan dan melihat kenyataan yang terjadi disekitarnya. Iman seseorang bisa saja dipertanyaan oleh dirinya sendiri, karena dipengaruhi dalam berbagai hal. Bisa saja di dalam keluarga, orang tersebut memiliki iman yang bagus, akan tetapi tidak menutup kemungkinan bahwa iman tersebut akan diragukan bahkan disingkirkan karena lebih percaya kepada apa yang dilihat bukan apa yang didengar. Selain persoalan tersebut, sisi positif pada tahap ini adalah kekuatan iman merupakan hal terpenting dalam kehidupan seseorang, di mana iman jauh lebih besar melapaui segala kekuatan yang dimiliki oleh seseorang. Artinya bahwa tahap ini menjadi tahap di mana seseorang dapat mengakui imannya sendiri. ${ }^{29}$ Bagian ini merupakan tahap di mana iman seseorang dapat tergoyahkan akibat banyak hal, kekayaan, kesibukan dan lain sebagainya, sehingga perlu ada edukasi yang benar dalam PAK. Marthen Sihertian menjelaskan bahwa edukasi yang dilakukan, adalah bisa melakukan kelompok sel untuk saling membangun, mengembangkan karunia rohani. 30

\footnotetext{
29 Feriyanto, "Implementasi Cerita Alkitab Terhadap Perkembangan Iman Anak Sekolah Minggu Gereja Toraja Menurut Teori James W. Fowler Di Jemaat Karassik." 13 $3^{0}$ Marthen Sahertian, "Pendidikan Agama Kristen Dalam Sudut Pandang John Dewey,” Jurnal Teruna Bhakti 1, no. 2 (2019): 101, https://doi.org/10.47131/jtb.v1i2.18.
} 
Selanjutnya dijelaskan oleh Yornan Masinabow dan Yosef Nasrani bahwa pada tahap ini diharapkan untuk pribadi tersebut mampu mengembangan dan terus menjaga kehidupan spiritualnya serta menjadi terang bagi sesamanya dengan cara mendorong sesamanya untuk hidup berdasarkan nilainilai Kristiani melalui pendidikan Kristen. ${ }^{31}$

Tahap Keenam, Fowler berpandangan bahwa tahap ini merupakan tahap tertinggi seseorang dalam perkembangan iman. Banyak hal akan dialami pada tahap ini, baik dalam dunia pekerjaan, keluarga, pendidikan, kebudayaan dan lain sebagainya. Tahap ini sebagai tahap di mana seseorang dianggap mencapai semua yang diinginkan dan berkomitmen untuk mampu mengatasi masalah dan persoalan yang menimpa hidupnya. Konflik tidak lagi dilihat sebagai hal yang baru, namun merupakan kenyataan yang harus dicari solusi untuk mengatasinya. Menurut penemu teori ini, tidak semua orang berhasil mencapai tahap perkembangan iman tertinggi ini. Banyak orang mengalami kegagalan karena dipengaruhi oleh banyak hal, sehingga hanya sedikit orang yang tekun bertahan yang mencapai tahap ini. Khusus tahap ini, Fowler memberikan contoh konkrit bahwa memang benar, hanya sedikit orang yang berhasil mencapai perkembangan iman tertinggi ini, antara lain: Mahatma Gandhi, Martin Luther King, Jr., dan Bunda Teresa. ${ }^{2}$

\section{Kesimpulan}

Berdasarkan pembahasan di atas, maka dapat disimpulkan bahwa teori perkembangan iman James Fowler sangat relevan pada Pendidikan Agama Kristen karena perkembangan iman seseorang dapat terjadi malalui beberapa tahapan, beberapa aspek dan hal lainnya.

\footnotetext{
${ }^{31}$ Yornan Masinambow and Yosef Nasrani,

"Pendidikan Kristiani Sebagai Sarana Pembentukan

Spiritualitas Generasi Milenial,” PASCA: Jurnal
}

Seperti pada penjelasan sebelumnya, bahwa Pendidikan Agama Kristen merupakan usaha sadar oleh setiap orang percaya demi mengajarkan serta mengaktualisasikan karya Kristus sebagai penyelamat di tengah-tengah dunia melalui berbagai pengalaman belajar yang dilaksanakan di berbagai bidang pendidikan baik formal (sekolah), informal (keluarga) dan non-formal (gereja). Dengan demikian didalam diri naradidik dapat dilihat indikator pertumbuhan rohani yang berkesinambungan melalui penghayatan terhadap iman kepada Allah itu dalam kehidupan sehari-hari dari hal-hal yang terkecil. Dengan mempelajari teori perkembangan iman dari James Fowler ini, maka tugas pendidik Kristen (semua orang percaya, khususnya orang tua, pendidik PAK/guru PAK, dan bahkan pelayan gereja) menjadi jauh lebih besar bukan hanya mentransfer Pengetahuan Isi Alkitab (PIA), tetapi lebih kepada penggembalaan iman akan apa yang dipercayai oleh naradidik.

Betapa pentingnya perkembangan iman Kristen naradidik sehingga teori yang dicetuskan oleh Fowler ini sangat bermanfaat bagi pendidikan pada berbagai bidang. Melalui teori ini para pendidik Kristen juga dapat membantu naradidik untuk berkomitmen penuh dalam imannya yang disesuaikan berdasarkan perkembangan usia itu. Maksudnya pendidik harus mengajarkan Iman Kristen kepada naradidik sesuai dengan kemampuan nalar dan berpikir berdasarkan usia naradidik tersebut sehingga iman mereka semakin bertumbuh pada fase atau tahapan berikutnya. Dengan demikian, dalam Pendidikan Agama Kristen tidak hanya memberikan teori kepada anak didik tapi menuntun dan membimbing anak-anak dalam hal pertumbuhan iman mereka sehingga iman percayaannya kepada Yesus Kristus tetap dipegang sejak ditanamkan pada masa kecil sampai pada masa dewasanya.

Teologi Dan Pendidikan Agama Kristen 17, no. 1 (2021), https://doi.org/10.46494/psc.v17i1.114. ${ }^{2}$ Saputra, "Perkembangan Spiritual Remaja SMA Dharma Putra", 62 


\section{Referensi}

Agoes Dariyo. Psikolgi Perkembangan Dewasa Muda. Jakarta: Grasindo, 2008.

Boiliu, Noh Ibrahim. "Misi Pendidikan Agama Kristen Dan Problem Moralitas Anak." Regula Fidei 1, no. 1 (2016): 115-40. http://repository.uki.ac.id/406/.

Djoys Anneke Rantung. PAK Dalam Kehidupan Majemuk. Yogyakarta: Lintang Rasi Aksara Books, 2017.

E.G. Homrighausen dan I. H. Enklaar. Pendidikan Agama Kristen. Jakarta: BPK Gunung Mulia, 2008.

Feriyanto. "Implementasi Cerita Alkitab Terhadap Perkembangan Iman Anak Sekolah Minggu Gereja Toraja Menurut Teori James W. Fowler Di Jemaat Karassik.” Cura Animarum 1, no. 1 (2019): 7-18.

Gulo, Ya'aman, Rita Evimalinda, and Ardianto Lahagu. "Peran PAK Dalam Membentuk Mental Positif Generasi Kristen Di Era Millenial.” Real Didache: Jurnal Teologi Dan Pendidikan Agama Kristen 5, no. 1 (2020): 17.

Hasudungan Simatupang, Ronny Simatupang \& Tianggur Medi Napitupulu. Pengantar Pendidikan Agama Kristen. Yogyakarta: PBMR ANDI, 2020.

Johan Hasan. "Sumbangsih Pemikiran James W. Fowler Dalam Pendidikan Agama Di Perguruan Tinggi Indonesia." Respons: Unika Atma Jaya 23, no. 02 (2018): 185204.

John Piper. The Pleasures Of God: Meditations ON God's Delight in Being God. Newyork: Multomah Publisher, 2012.

Masinambow, Yornan, and Yosef Nasrani. "Pendidikan Kristiani Sebagai Sarana Pembentukan Spiritualitas Generasi Milenial.” PASCA: Jurnal Teologi Dan Pendidikan Agama Kristen 17, no. 1 (2021). https://doi.org/10.46494/psc.v17i1.114.

Minggus. "Pembelajaran Kontekstual Di Masa Pandemi Untuk Mengembangkan Spiritualitas Anak." PASCA: Jurnal Teologi Dan Pendidikan Agama Kristen, 2021. https://doi.org/10.46494/psc.v17i1.126.

Nuhamara, Daniel. Pendidikan Agama Kristen Remaja. Bandung: Jurnal Info Media, 2008.
Kristen. Jakarta: BPK Gunung Mulia, 2018.

Ruwi Hastuti. "Pendidikan Agama Kristen Dalam Keluarga Sebagai Pusat Bermisi.” Konfrensi Keluarga Kristen - The Great Commission 25, no. Juni (2018): 75-92.

Sahertian, Marthen. "Pendidikan Agama Kristen Dalam Sudut Pandang John Dewey.” Jurnal Teruna Bhakti 1, no. 2 (2019): 101. https://doi.org/10.47131/jtb.v1i2.18.

Saputra, Denny Surya. "Perkembangan Spiritual Remaja SMA Dharma Putra." Jurnal Psikologi 15, no. 9 (2018): 64 of 67.

Setyaningsih. "Dampak Globalisasi Terhadap Generasi Muda.” STHD Jateng 148 (2019): 148-62.

Suanglangi, Hermanto. "Iman Kristen Dan Akal Budi.” Jurnal Jaffray 2, no. 2 (2005). https://doi.org/10.25278/jj71.v2i2.16o.

Tafonao, Talizaro. "Peran Pendidikan Agama Kristen Dalam Keluarga Terhadap Perilaku Anak." Edudikara: Jurnal Pendidikan Dan Pembelajaran 3, no. 2 (2018).

Zaluchu, Sonny Eli. “Metode Penelitian Di Dalam Manuskrip Jurnal Ilmiah Keagamaan [Research Methods in Religious Scientific Journal Manuscripts].” Jurnal Teologi Berita Hidup 3, no. 2 (March 25, 2021): 249-66. https://doi.org/10.38189/jtbh.v3i2.93.

-_-. "Model Pendidikan Nasionalis-Religius Yahudi, Dan Refleksinya Dalam Pendidikan Teologi Di Indonesia." KURIOS (Jurnal Teologi Dan Pendidikan Agama Kristen) 7, no. 2 (2021): 232-42. https://doi.org/https://doi.org/10.30995/k ur.v7i2.299.

Zega, Yunardi Kristian. “Teori Perkembangan Iman Remaja Menurut James Fowler Dan Implikasinya Bagi Pendidikan Agama Kristen.” Jurnal Pendidikan Dan Kebudayaan Missio 12, no. 2 (2020): 14051. https://doi.org/https://doi.org/10.36928/jp km.v12i2.488. 